Asian Journal of Managerial Science

ISSN: 2249-6300 Vol.7 No.2, 2018, pp.7-15

(C) The Research Publication, www.trp.org.in

\title{
The Demography of Socially Responsible Investors across Countries and Time: A Systematic Review
}

\author{
Anjum Ubaid Siddiqui \\ Research Scholar, Department of Business Administration, Aligarh Muslim University, Aligarh, Uttar Pradesh, India \\ E-Mail: anjum.ubaid12@gmail.com
}

\begin{abstract}
The field of investment has received considerable changes in recent years. Over the past decade one of the major trends in the finance domain is the emergence of Socially Responsible Investments, reflecting the increasing awareness of investors to social and environmental and corporate governance issues. Over the past three decades many surveys have been conducted to understand and segment the demographic profile of socially responsible investors. This article aims to provide an overview of the existing literature on the demographic characteristics of socially responsible investors that has been studied across countries and time.We have limited our focus to insights generated by the articles specifically, dealing with relative influence of sociodemographic factors on the attitude towards Socially Responsible Investment, as opposed to broadening the scope of our inquiry to a larger set of studies related to the SRI such as fund performance, financial risk/return characteristics etc. The articles published have been classified into four broad demographic categories viz. Age, Gender, Education and Income on the basis of the importance of each category in context of Socially Responsible Investment. Finally the conclusion and future research directions are suggested which would be of importance for both academicians and investment world.
\end{abstract}

Keywords: socially responsible investing, demographics, screening strategy, demographic factors

\section{INTRODUCTION}

Socially Responsible Investment also known as ethical investing, sustainable investing or green investments refers to the idea of taking into account environmental, social and government considerations in the investment process. According to Renneboog et. al., (2008b), Socially Responsible investing is a p rocess that integrates social, environmental and ethical considerations in investment decision making. The foundation and values behind SRI are ancient and dates back to the period of Jewish and Islamic traditions. Unlike the traditional type of investments, the SRI approach is to select stocks based on ecological, corporate governance and ethical criteria and eschew those that are involved in 'offending actions' to the society and the environment. Socially responsible investing (SRI) has gone from a fringe idea to a mainstream investment strategy on the capital market, as the investors are becoming more aware of social, ethical, environmental and corporate governance issues. In its infancy, Sustainable Investing emphasized the avoidance of companies involved in production of alcohol, tobacco and gambling. Today, the field is characterized by greater emphasis on social and political sophistication and numerous screening criteria's are used in socially responsible investments to create a portfolio, which is within the ethical framework of SRI. This can be achieved by limiting the investment universe and applying different screening processes when selecting share for the portfolio. In general, it includes the following:

Negative screening strategy (avoidance of companies engaged in unethical practices), Positive or Inclusion strategy (Including and rewarding companies which are working towards societal welfare, following the ethical code of conduct and are environment friendly), Shareholders activism where shareholders can influence the environmental, social and ethical policies of the companies they are engaged in, Community Investing and Impact Investing (where the investment is targeted for the benefit of a special community or group). These screens act as filters to the portfolio and throughout the process investors and financial institutions seek to guarantee sustainability within financial sector by integrating SRI principles in their operations

Going through the existing literature on SRI, one common theme that has emerged is that the majority of studies focus on the relative performance of SRI and Conventional funds and there are various articles listing the studies conducted till date. By focusing their argument on comparative investment performance, these studies have examined the aggregate structure of the Socially responsible funds, at the expense of deepening our understanding of the investors' role in SR investment decision. These studies have concealed the intricate framework of individual investment decision. Hence, performance related studies are excluded from this review. This study is a summary of the published scientific research showing the characteristics, similarities and the differences in the demographic profile of investors across countries and time. Divided into four sub-categories on the basis of demographic characteristics, impacting the investment in socially responsible funds, the articles are summarized as well as presented in a tabular form (see: Appendix-A attached) highlighting, geographical distribution of the surveys, the methodology adopted and the findings of each of the studies associated with socially responsible investment decision. Further, the findings and the gaps in the existing literature that will hopefully be filled by future research are discussed. This research may help to reveal a particular profile of socially responsible 
investors and help companies to identify potential investors for such type of funds.

\section{DESIGN AND METHODOLOGY}

The objective of this article is to highlight key papers that made substantive and conceptual contribution in the area of socially responsible investment and which have been published in different academic Journals from 1991 to 2016. We have included reference to all articles published during these twenty five years highlighting, the countries in which they have been carried out, sample size, method adopted for the study, the key variables under consideration and the key findings of each article. Although these articles may contain multiple contributions and these contributions could have been classified into multiple categories, we have chosen those categories that we believe are most appropriate with respect to each article listed. To identify the relevant literature for the review, we have carried out a s ystematic search through keywords identified from the currently available literature. The papers were gathered from major library sources and databases (Pro-quest, Emerald, Sciencedirect, Jstor, EBSCO).

\section{LITERATURE REVIEW}

Following the rapid growth of SRI, interest in such type of investments increased and many surveys have been conducted to better understand the characteristics of the ethical Investors. These investors are also called socially responsible or sustainable or green investors (Delmass and Blass, 2010; Heinkel et. al., 2001; Cheah et. al., 2011). For the purpose of this research we will use all these terms synonymously and define SR investors as those who hold at least one SR stock or mutual fund that can be a stock of a company or a fund with social orientation, good governance, focused on environment or a combination of both. On the other hand, conventional investors are just rational investors who make investment on the basis of risk and returns of the portfolio.

The Literature on socio demographic characteristic of investor is usually been presented first in most surveys. A number of studies have attempted to focus on socio demographics because of its correlation with ecological attitudes and the role it plays in shaping the perception and behavior concerning Social Responsibility. A careful examination of socio demographic characteristics of Socially Responsible Investors is important in itself, as this can help to identify specific demographic attributes of Investors, which have a significant bearing on their Investment decisions, thereby, influencing the attitude towards SRI. Majority of studies have often emphasized on the Age, Gender, Income and Education as the main demographic variables, to measure and understand the behaviour of investors. These factors have been frequently researched so far in the existing literature and in some way, connected with Socially responsible investment attitude.

\section{Age}

Notable researchers have studied the variable 'Age'. There are studies that indicate that age is not significantly associated with the attitude towards SRI. (Chan.K 1999; Gatzner \& Krauter 2014; Viviers et al.,., ; Nilsson 2008; Mclachlan and Gardener 2004; Williams 2007; Wins and Zwergel, 2016) . On the other hand researchers have also hinted that investors of different age group have different attitude towards SRI holdings. (Rosen et. al 1991; Hayes 2001; Diamantopoulos et al.,. 2003; Schueth 2003; Cheah et al.,. (2011); Bauer and Smeets 2015) .For example, Rosen et al., (1991) conducted a survey of Individual Investors in US and concluded that Socially Responsible investors are younger as compared to conventional investors. The findings are in line with a study by Tippet and Leung (2011) on Australian equity investors. The results indicate that the majority of ethical investors within the sample were much younger and aged between 35-44 years. Similarly, Junkus and Berry (2010) surveyed a large group of well-informed US investors to determine whether SR investor have a particular demographic profile and whether this profile is different from that of conventional investors.The authors found that SR investors are younger than traditional investors. Likewise, Cheah et al.,. (2011) revealed that age and SR attitude are linked to together as young investors are not particularly concerned about a co mpany's wealth maximization and are prepared to accept the ethical penalty. Again, Bauer and Smeets (2015) in a study conducted in Netherland; advocate that the perception of belonging to a particular social group is stronger among young investors. In a r ecent study, conducted by Dorfleitner and Nguyen (2016) on German investors, the authors examine the optimal proportion of Socially responsible investment when forming their portfolio. The results show that younger people seek to invest a higher percentage of their portfolio in socially responsible investment options.

In contrast to the above-mentioned arguments many studies have found that Socially Responsible investors belong to a middle age group or older. (Mackenzie and Lewis, 2000; Perez-Gladish et al.,. 2012;E.Escrig-Olmedo et al.,. 2013; De Silva and Pownall 2013). Mackenzie and Lewis (2000) found that typical ethical investors are middle- aged professionals. Corroborating the findings was PerezGladish et al.,. (2012) who examined the financial preference and socio demographic characteristics of Australian Investors and argued that SR investors tend to be in the middle age category. Similarly, E.Escrig-Olmedo et al.,. (2013) analyzed the Spanish investors' perception about socially responsible investment and their preferences regarding social, environmental and governance criteria and found that most of the investors are in the late middle age. The findings of an earlier study by Beal and Goyen (1998) also support the view that older investors are more concerned about environmental issues and are more likely to invest in companies, which conserve ecosystem. On similar lines, De Silva and Pownall (2013) studied the individual preferences towards the environment, social 
wellbeing and financial wellbeing of households in Netherland. The results showed that age is an important factor in determining the willingness to reduce carbon emission and people are willing to sacrifice a part of financial wellbeing for the same. Majority of them belong to an older age group.

While the above-mentioned studies suggest a link between age and SR attitude, several authors are of the view that there is no significant association between age and SR attitude. McLachlan and Gardner (2004) compared the conventional and socially responsible investors in Australia, with the aim of identifying factors that lead the investor to choose Socially Responsible Investment products. The study found no evidence of difference in the age between socially responsible and conventional investors. Similarly, Getzner and Krauter (2004) studied the Austrian market for private investors regarding their willingness to invest in green shares. The study highlighted that age was positively associated with ecological attitude but less influential on the perception of environmental problems. It can be an explanation for the type of investment with younger being more risk friendly than older investors. Williams (2007) drew data from a 1 arge survey of investors across five countries namely Australia, Germany, Canada, UK and US and focused on some key factors that are potential determinants of Socially Responsible Investment choice .The author found little evidence that demographic factors affect SRI attitude. Further, Wins and Zwergel (2016) presented the results of an online survey of German mutual fund investors to show that there was no difference in the age of investors who were interested in Socially Responsible products and Investors who choose conventional options to diversify their portfolio. It is evident, from the above discussion that there are contradictory findings related to age and its impact on SR investment decision.

\section{Gender}

Another important demographic variable is the gender. There is empirical evidence that significant differences exist in the investment preferences of male and female (Laroche et al.,., 2001; Schueth 2003; Tippet and Leung, 2001; Junkus and Berry 2010;. DeSilva and Pownall (2013); Cheah et al.,. 2011; E.Escrig-Olmedo et al., (2013). Studies have shown that there is difference between attitude, cognitive abilities and decision-making style of males and females and these factors shape their perception of moral intensity. Hence, gender may influence their SRI attitude. Researchers have found that women are more inclined towards environmentalism and more socially responsible and are likely to invest greater proportion of their portfolio in SRI. (Laroche et al.,. 2001; Schueth 2003). The findings of an early study conducted by Beal and Goyen (1998) in Australia, on a co mpany that conserved ecosystem and engaged in the saving of endangered species as its corporate mission, revealed that the shareholders are more likely to be female rather than male. Tippet and Leung (2001) compared the average and ethical investors in Australia and found a strong gender effect, with females predominating the male investors. Likewise, Schueth (2003) observed that women have "brought a natural affinity to the concept of socially responsible investing with them". As such about 60 percent of the investors in US are women. In addition to this, a study conducted by Nilsson (2008) on mutual fund investors, revealed that socio demographic variables are connected to SR investment behavior and women are more likely to invest a greater proportion of their wealth in Socially Responsible Investment. Similarly, Cheah et al.,. (2011) also found that female Investors place at least as much importance to company's social; environmental and ethical performance when making investment decisions, as their concern for financial returns.

In addition to this, DeSilva and Pownall (2013) assert that females put greatest value on both people and planet. They are more socially oriented and are willing to reduce their current standard of living to maintain the environment. The authors suggest that gender has an important influence on sustainability. Viviers et al.,. (2012) also emphasized the importance of gender in context of ethics, environment, social and governance criteria. The results of the study indicated a significant difference in the perception of male and female with regard to the relative importance attached to ESG. Likewise, E.Escrig-Olmedo et al.,. (2013) examined the public perception towards Socially Responsible Investments and found that gender has a positive and statistically significant impact on the probability of deciding to invest in SRI funds. Women are more likely to invest according to social aspects than men. The analysis of the main motives of investors in allocating a part of their portfolio in socially responsible investment also revealed, that gender is an important inducement for SR investing (Dorfleitner and Utz 2014; Bauer and Smeets, 2015) The findings show that women are willing to sacrifice significantly higher returns for high levels of social responsibility. Furthermore, the findings of an exploratory study conducted by Wins and Zwergel (2016), also indicate that compared to males the proportion of female investors rises with rising personal involvement to $\mathrm{SR}$ issues. Dorfleitner and Nguyen (2016), suggests that female investors care more about human rights and providing donations. They are more likely to seek a higher optimal proportion that is invested sustainably.

While the above studies supported the general belief that SR investors are more likely to be female there are few findings where the effect of gender is not significantly associated with SR investment behavior. Lewis and Mackenzie (2000) reported an almost balanced gender proportion while doing an empirical study on who invests in SRI. In the same way, Williams (2007) carried out a cross-country analysis of SRI investors in different context and points out that gender appears to explain very little about the SR attitude and is not statistically significant. Likewise, Haigh (2008) noticed a balanced proportion of males and females in his study to find out the motivation behind investing in social funds. Similarly, Nga and Yien (2013) analyzed the impact of 
gender, in the study, carried out to investigate the influence of personality traits and demographics on financial decision making dimensions among generation Y, in Malaysia. They found that gender has no influence in financial decisionmaking. In summary, while there are some variations to the role of gender and its association with SR attitude, the general belief is relatively consistent that females tend to be more inclined towards Ethical Social and Environmental issues.

\section{Income}

The level of income may have a significant impact on the attitude to invest responsibly. This is proved to be true in some studies that SR investors belong to the higher income group, the main reason being the Individuals with higher income can bear the cost associated with supporting ecological and ethical causes (Tippet and Leung, 2001; Beal and Goyen, 1998; Getzner and Krauter, 2004; Dorfleitner and Utz 2014, Cheah et al., 2011). For example, Tippet and Leung (2001) suggested ethical investors to be wealthier and more able to accommodate the cost of favouring Social Environmental and Ethical Investment options. Beal and Goyen (1998) revealed that the shareholders are more likely to be metropolitan residents with significantly higher level of socio-economic status and household assets i.e. with high levels of income. The importance of high-income level was also demonstrated by Dorfleitner and Utz (2014) The authors carried out an online survey of German speaking investors to examine the influence of Investment volumes on SR investing, as the former, is directly related to high level of wealth. In the study, the respondents with high investment volumes were more familiar with SR investments and as such the results indicate that the relative frequency of investment in Socially Responsible funds increases with the increase in investment volume.

Contrary to the above-mentioned studies, there are significant number of studies, which show that income has no connect with SR investment (Nilsson 2008, McLachlan and Gardner 2004; Williams 2007; DeSilva and Pownall 2013; Wins and Zwergel, 2016). In this regard, (McLachlan and Gardner, 2004; Wins and Zwergel, 2016) compared the demographics of Socially Responsible Investors and Conventional Investors in Australia and found no significant difference in income levels of both group of investors. Similarly, Williams (2007) carried out a survey across US, UK and Europe and found that demographic factors are of little significance and are mostly statistically insignificant. Bringing more clarity on the subject, Nilsson (2008) has suggested that Income has no effect on the Socially Responsible Investment behavior.

Additional research in this area includes studies, which claim that Socially responsible investors are less influential and have lower median incomes. Rosen et al.,. (1991) propounds the view that socially responsible investors are less affluent than their conventional counterparts. They have low median household income. The study by Junkus and Berry (2010) lends support to this claim that socially responsible investors are slightly but significantly less wealthy then conventional investors. Lewis and MacKenzie (2000) also, provide evidence of SR Investors belonging to middle income group. The foregoing discussion implies that there are contradictory findings on the level of income and its impact on Socially Responsible Investment behavior.

\section{Education}

The impact of Education on SR attitude has also been studied by a 1 arge number of researchers. Education is generally thought to be positively correlated with ecological concerns and ethical behavior (Rosen et al., 1991, Beal and Goyen, 1998; Chan, 1999;Prez-Gladish et al., 2012; De Silva and Pownall 2013; Tippet and Leung 2001;Getzner and Krauter 2004;Haigh 2008;Nilsson 2008). In one of the very early studies, performed by Rosen et al.,. (1991) on US investors. The authors put forth the view that Socially Responsible Investors are better educated. Beal and Goyen (1998) also reported significantly high level of education, in the study carried out on the shareholders of a co mpany engaged in conservation of nature. Tippet and Leung (2001) compared the ethical and equity investors in Australia and found that ethical investors were highly educated having degree or higher degree qualifications. The study by Schueth (2003) on US investors to find out what is fuelling the growth of SR Investment lends support to the claim that education creates a more informed society. The author pointed out the fact that US investors are better educated and well informed today as compared to the earlier generation and most importantly, better informed investors are more responsible in their actions to be. Nilsson (2008) also supports the notion that better educated investors are more likely to invest a greater proportion of their investment portfolio in SRI. This shows that the level of education explains their demand for Socially Responsible investments.

Corroborating the findings of previous researchers, Junkus and Berry (2010) also hinted that typical SR investors are more qualified than their non-SR counterparts. Simultaneously, Cheah et al., (2011) believed that the perception of better educated SRI's regarding the conduct of companies' activities and their impact on the environment and the society at large will have significant influence on the investment decisions. The same consistency is observed in the study conducted by Viviers et al.,. (2012) as there was significant difference in the education of the respondents with regard to the relative importance attached to Ethical, Social and Governance criteria. E.Escrig Olmedo et al.,. (2012) also suggested that the people with high level of education have $a b$ etter knowledge of SRI and Sustainability rating agencies and Ethical banking and hence, they are more likely to invest in such products. Likewise, Bauer and Smeets (2015) studied the role of social identification (strong social preference and assumption of being pro social) in investment decision in context of SRI. The study revealed that having a University degree was positively correlated to social identification. 
Contrary to this, it has also been observed that education plays an insignificant role in ethical investment decision (Williams 2007; Nga and Yein 2013;Mclachlan and Gardener 2004). Nga and Yein (2013) aimed to investigate the influence of education on financial decision making dimensions and found that education was insignificant predictor of SR investment decision. McLachlan and Gardener, (2004) also support the view that conventional and SR investors do not differ significantly as far as education is concerned.

Overall, there is an inconclusive debate on the relationship between socio-demographic characteristics and its impact on SRI attitude, mentioned above. Nevertheless, it is evident from the foregoing discussion that each study suggests a link between SR attitude and Investor demographics. It can be assumed that demographic variables are important predictors of SRI behavior and hence are to be considered when the topic under consideration is socially responsible investments.

\section{CONCLUSION}

The overview of the literature relating to the demographic has shown that Asia, Africa and South America are completely under-researched. The distributions concerning demographic variables vary substantially due to the variability of the population under study, the sample size and methods adopted and hence a clear demographic profile of a typical SR investor cannot be crystallized. In addition to this the literature supports the view that SR investors are heterogeneous group of population. Although many studies have focused on Australia, Europe and North America, one cannot draw a conclusion about a unifying characteristic of socially responsible investor. The findings are in line with the conclusion drawn by Diamantopoulos et. al., (2003) that, demographic factors are of little use for segmenting and targeting environmentally conscious behavior. Nevertheless, examining the demographics may help to identify specific attributes of typical SR investors, which will help sustainable companies to design their investment products aimed at attracting particular group of investors. Our conclusion clearly hints in a direction but to bring about more clarity and comparability an in-depth representative study across different countries under similar conditions and with similar samples should be conducted in future that will help fund houses to design products that appeal to SR investors.

TABLE I CONCLUSION ON VARIABLES

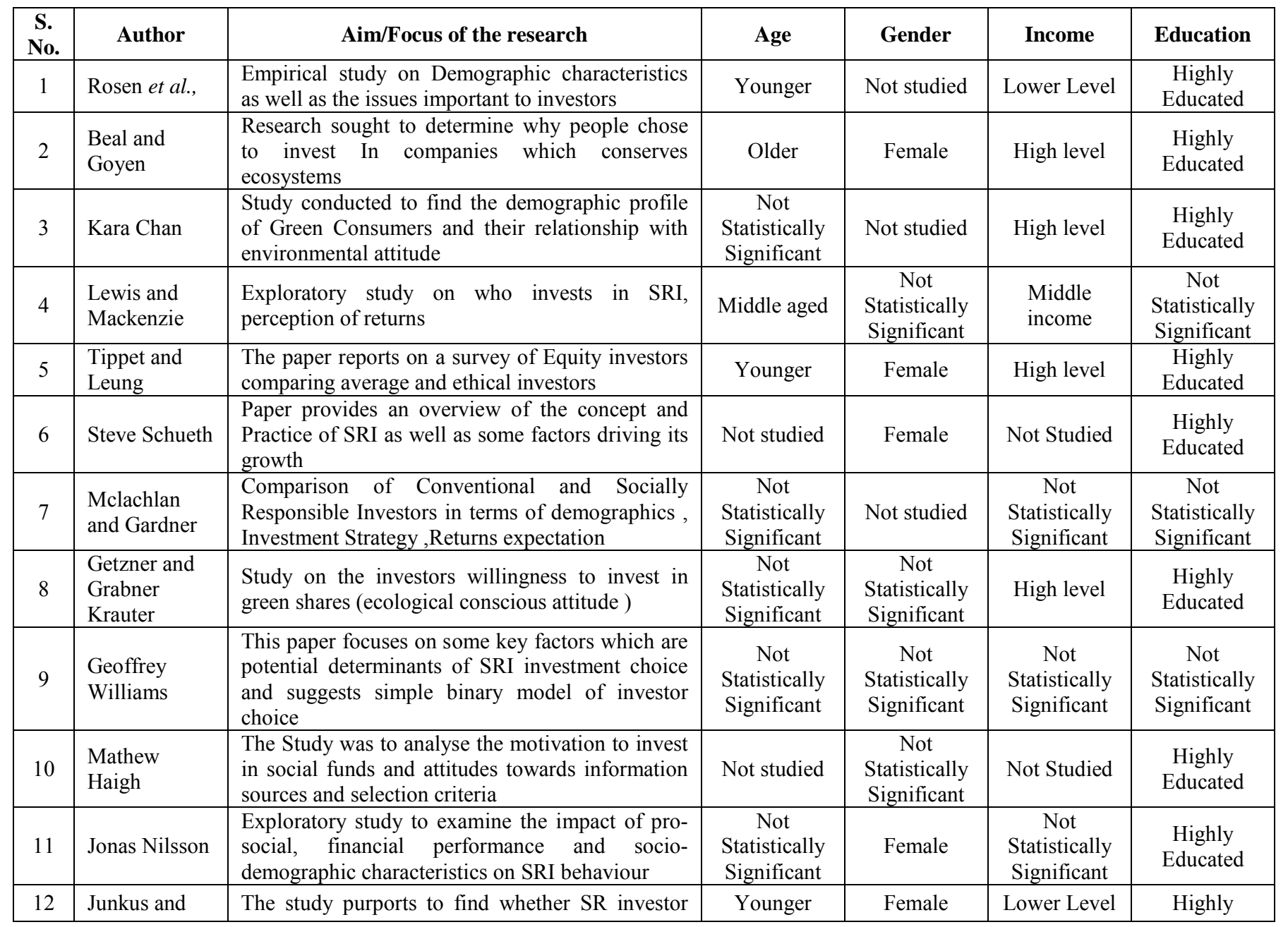




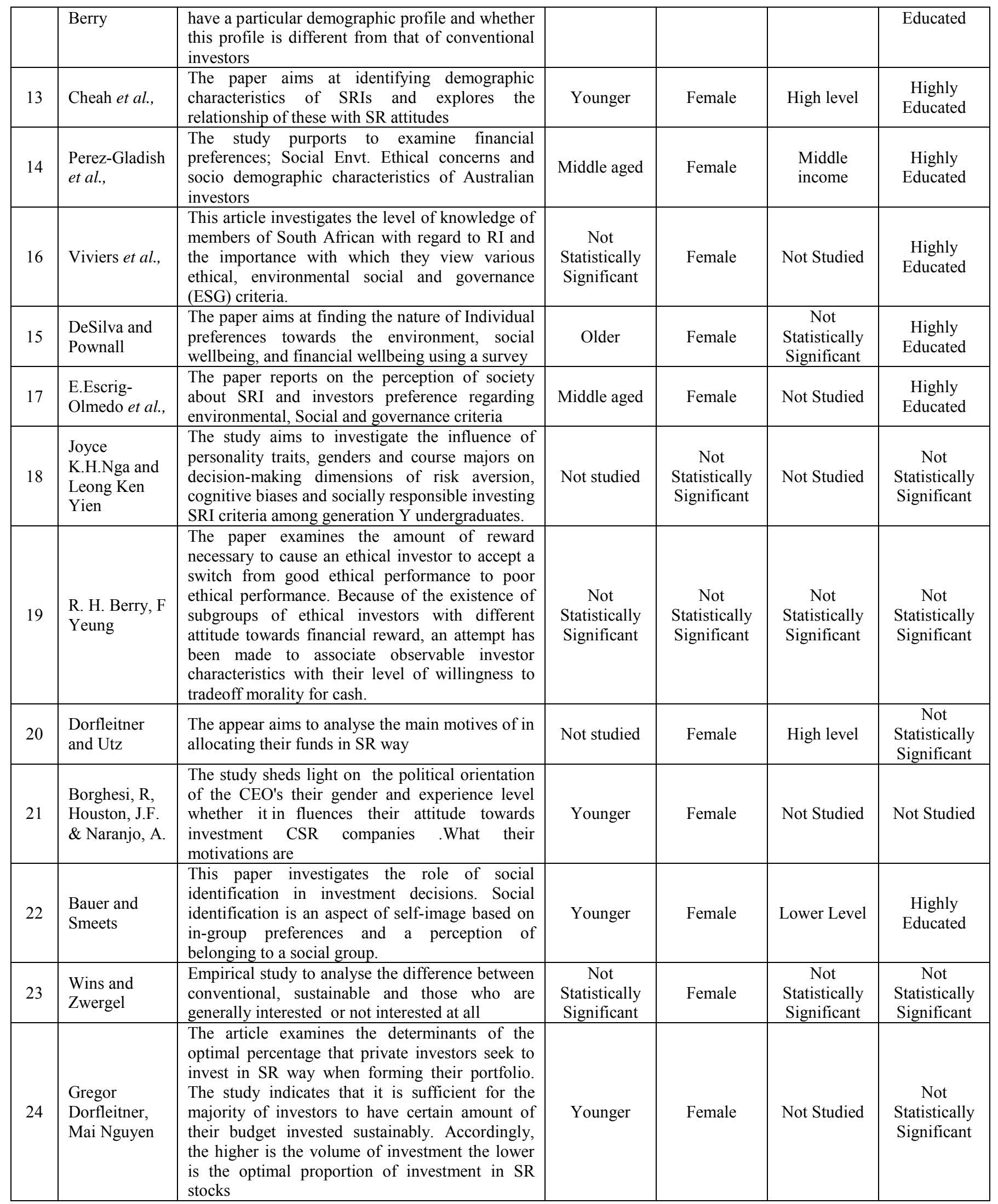


TABLE II METHODOLOGY ADOPTED (Q-QUESTIONNAIRE/I-INTERVIEWS/D-DISCUSSION

\begin{tabular}{|c|c|c|c|c|c|}
\hline S. No. & Author & Sample size & Investor type & Methodology & Findings/Summary \\
\hline 1 & Rosen et al., . & 1493 & Individual & Q & $\begin{array}{l}\text { SR-Investors were younger, better educated, but less } \\
\text { affluent than the conventional investors. }\end{array}$ \\
\hline 2 & $\begin{array}{l}\text { Beal and } \\
\text { Goyen }\end{array}$ & 739 & Individual & Q & $\begin{array}{l}\text { The investors were more likely to be female, highly } \\
\text { educated, older and having higher household assets }\end{array}$ \\
\hline 3 & Kara Chan & 704 & Individual & I & $\begin{array}{l}\text { Green consumers were more likely to be highly educated } \\
\text { and with high levels of income }\end{array}$ \\
\hline 4 & $\begin{array}{l}\text { Lewis and } \\
\text { Mackenzie }\end{array}$ & 1146 & Individual & Q & $\begin{array}{l}\text { Results indicated that SR investors are more likely to be in } \\
\text { the middle age and income group }\end{array}$ \\
\hline 6 & Steve Schueth & NA & NA & $\mathrm{D}$ & $\begin{array}{l}60 \% \text { of the SR investors in US are female as females bring } \\
\text { a natural affinity to the concept of SR investing and are } \\
\text { rather more qualified }\end{array}$ \\
\hline 8 & $\begin{array}{l}\text { Getzner and } \\
\text { Grabner } \\
\text { Krauter }\end{array}$ & 400 & Individual & I & $\begin{array}{l}\text { Econometric estimates explained that income and } \\
\text { education were also the explanatory variables in } \\
\text { respondent's willingness to invest, apart from } \\
\text { environmental awareness and expected profits. }\end{array}$ \\
\hline 9 & $\begin{array}{l}\text { Geoffrey } \\
\text { Williams }\end{array}$ & 1000 & Individual & Q & $\begin{array}{l}\text { The author found that investor attitude towards social aims } \\
\text { of the firm is the driving force behind SRI. Also, there was } \\
\text { little evidence that demographic factors affect SRI attitude }\end{array}$ \\
\hline 10 & Mathew Haigh & 382 & Individual & Q & $\begin{array}{l}\text { Results indicate that investors were attracted due to their } \\
\text { moral convictions and from desires to influence corporate } \\
\text { behaviour. There was a slightly more percentage of males } \\
\text { with high levels of education }\end{array}$ \\
\hline 14 & $\begin{array}{l}\text { Perez-Gladish } \\
\text { et al.,. }\end{array}$ & 145 & Individual & Q & $\begin{array}{l}\text { The authors found that investors seek financial returns as } \\
\text { well as non-financial benefits. They are in the middle age } \\
\text { category with middle income and tertiary qualification }\end{array}$ \\
\hline 16 & Viviers et al.,. & 281 & Individual & Q & $\begin{array}{l}\text { The study revealed that female attaches more importance } \\
\text { to the ESG criteria as compared to males. Also the higher } \\
\text { the level of education the greater the perceived importance } \\
\text { of philanthropy policies and practices }\end{array}$ \\
\hline 15 & $\begin{array}{l}\text { DeSilva and } \\
\text { Pownall }\end{array}$ & 1400 & Individual & Q & $\begin{array}{l}\text { The study found that gender and education are important } \\
\text { factors of sustainability rather than income levels. The } \\
\text { results indicate that educated females put the greatest value } \\
\text { on going green whilst being socially minded. }\end{array}$ \\
\hline 17 & $\begin{array}{l}\text { E.Escrig- } \\
\text { Olmedo et al.,. }\end{array}$ & 345 & Individual & Q & $\begin{array}{l}\text { Education and Occupation were most important } \\
\text { determinants when making investment decision. Lack of } \\
\text { awareness about SRI was observed in the survey }\end{array}$ \\
\hline 18 & $\begin{array}{l}\text { Joyce K.H.Nga } \\
\text { and Leong Ken } \\
\text { Yien }\end{array}$ & 314 & Individual & Q & $\begin{array}{l}\text { The study found that gender and education was } \\
\text { insignificant, However, females tended to be more risk } \\
\text { averse and were more willing to subscribe to SRI. Males } \\
\text { relied on cognitive bias. The respondents who were } \\
\text { enrolled in an accounting and finance course were more } \\
\text { risk averse hence opted for SRI }\end{array}$ \\
\hline
\end{tabular}




\begin{tabular}{|c|c|c|c|c|c|}
\hline 19 & $\begin{array}{l}\text { R. H. Berry, } \\
\text { F Yeung }\end{array}$ & 192 & Individual & Q & $\begin{array}{l}\text { Ownership of a high-value portfolio and possession of a } \\
\text { high income have the reverse effect. This is an unexpected } \\
\text { result since the income variable, at least, might be thought } \\
\text { to be associated with a diminished concern with further } \\
\text { financial gain. }\end{array}$ \\
\hline 20 & $\begin{array}{l}\text { Dorfleitner and } \\
\text { Utz }\end{array}$ & 354 & $\begin{array}{l}\text { Individual, } \\
\text { Institutional and } \\
\text { asset managers }\end{array}$ & Q & $\begin{array}{l}\text { The study indicates that Gender and Investment volume } \\
\text { are explanatory variables in SRI attitude }\end{array}$ \\
\hline 21 & $\begin{array}{l}\text { Borghesi, R, } \\
\text { Houston, J.F. } \\
\text { \& Naranjo, A. }\end{array}$ & 11711 & Asset Managers & Q & $\begin{array}{l}\text { Female and Younger CEO'S are more inclined towards } \\
\text { SRI }\end{array}$ \\
\hline 22 & $\begin{array}{l}\text { Bauer and } \\
\text { Smeets }\end{array}$ & 3187 & Individual & Q & $\begin{array}{l}\text { The results of the study revealed that social identification } \\
\text { (inclination towards SRI by identifying oneself as pro } \\
\text { social) is strong between highly educated, female and low } \\
\text { wealth investors. }\end{array}$ \\
\hline 23 & $\begin{array}{l}\text { Wins and } \\
\text { Zwergel }\end{array}$ & 421 & Individual & Q & $\begin{array}{l}\text { The analysis revealed a picture of clear difference between } \\
\text { three types of investors. Difference in attitudes and } \\
\text { motives are the determining factors and the study also } \\
\text { supports the view that SR investors are more likely to be } \\
\text { female }\end{array}$ \\
\hline 24 & $\begin{array}{l}\text { Gregor } \\
\text { Dorfleitner, } \\
\text { Mai Nguyen }\end{array}$ & 381 & Individual & Q & Young and female investors seek to invest responsibly \\
\hline
\end{tabular}

\section{REFERENCES}

[1] Rob Bauer, and Smeets, Paul, "Social Identification and Investment Decisions", Journal of Economic Behaviour and Organization (April 24, 2015).

[2] Beal, D. and Goyen, M. (1998), “'Putting your money where your mouth is' a profile of ethical investors", Financial Services Review, Vol. 7 No. 2, pp. 129-143.

[3] Berry, R.H. and Yeung, F. (2013), "Are investors willing to sacrifice cash for morality?." Journal of Business Ethics, Vol. 117 No. 3, pp. 477-492

[4] Borghesi, R., Houston, J. F., \& Naranjo, A. (2014). Corporate socially responsible investments: CEO altruism, reputation, and shareholder interests., Journal of Corporate Finance, 26, 164-181.

[5] Chan, K. (1999), "Market segmentation of green consumers in Hong Kong", Journal of International Consumer Marketing, Vol. 12 No. 2, pp. 7-24.

[6] Cheah, E.-T., Jamali, D., Johnson, J.E. and Sung, M.-C. (2011), "Drivers of corporate social responsibility attitudes: the demography of socially responsible investors", British Journal of Management, Vol. 22 No. 2,pp. 305-323

[7] Delmas, M. and Blass, V.D. (2010), "Measuring corporate environmental performance: the trade-offs of sustainability ratings", Business Strategy and the Environment, Vol. 19 No. 4, pp. $245-260$

[8] De Silva .D \& Rachel A. J. Pownall (2013) Going green: does it depend on education, gender or income? Applied Economics, 46:5, 573-586, (Working paper)

[9] Diamantopoulos, A., Schlegelmilch, B.B., Sinkovics, R.R. and Bohlen, G.M. (2003), "Can socio-demographics still play a role in pro ling green consumers? A review of the evidence and an empirical investigation", Journal of Business Research, Vol. 56 No. 6, pp. 465-480.

[10] Dorfleitner, G. and Utz, S. (2014), "Profiling German-speaking socially responsible investors", Qualitative Research in Financial Markets, Vol. 6 No. 2, pp. 118-156

[11] Dorfleitner,G. and Nguyen. M. (2016) "Which proportion of SR investment is enough? A survey based approach", Business Research, Vol. 9 pp. 1-25.

[12] E. Escrig-Olmedo, E., Muñoz-Torres, M.J. and FernándezIzquierdo, M.Á. (2013), "Sustainable development and the financial system: society's perceptions about socially responsible investing”, Business Strategy and the Environment, Vol. 22 No. 6, pp. 410-428.

[13] Getzner, M. and Grabner-Krauter, S. (2004), "Consumer preferences and marketing strategies for 'green share' specifics of
Austrian market", International Journal of Bank Marketing, Vol. 22.No.4, pp. $260-79$

[14] Hayes, J. (2001). “ The greater good: how ethical investment pays off”, Australian Financial Review, 26-27, pp. 29-31

[15] Haigh, M. (2008), "What counts in social managed investments: evidence from an international survey", Advances in Public Interest Accounting, Vol. 13, pp. 35-62.

[16] Heinkel, R., Kraus, A. and Zechner, J. (2001), "The effect of green investment on corporate behavior", The Journal of Financial and Quantitative Analysis, Vol. 36 No. 4, pp. 431-449.

[17] Junkus, J.C. and Berry, T.C. (2010), "The demographic profile of socially responsible investors", Managerial Finance, Vol. 36 No. 6, pp. 474-481.

[18] Joyce K.H. Nga, Leong Ken Yien, (2013) "The influence of personality trait and demographics on financial decision making among Generation Y", Young Consumers, Vol. 14 Issue: 3, pp. $230-243$

[19] Lewis, A. and Mackenzie, C. (2000a), "Morals, money, ethical investing and economic psychology", Human Relations, Vol. 53 No. 2, pp. 179-191.

[20] Laroche, M., Bergeron, J. and Barbaro-Forleo, G. (2001), "Targeting consumers who are willing to pay more for environmentally friendly products", Journal of Consumer Marketing, Vol. 18 No. 6, pp. 503-520.

[21] McLachlan, J. and Gardner, J. (2004), "A comparison of socially responsible and conventional investors", Journal of Business Ethics, Vol. 52 No. 1, pp. 11-25

[22] Nilsson, J. (2008), "Investment with a conscience: examining the impact of pro-social attitudes and perceived financial performance on socially responsible investment behavior", Journal of Business Ethics, Vol. 83 No. 2, pp. 307-325.

[23] Pérez-Gladish, B., Benson, K. and Faff, R. (2012), "Profiling socially responsible investors: Australian evidence", Australian Journal of Management, Vol. 37 No. 2, p. 189.

[24] Renneboog, Luc, Ter Horst, Jenke and Zhang, Chendi (2008) Socially responsible Investments: institutional aspects, performance, and investor behavior. Journal of Banking \& Finance, Vol.32 (No.9). pp. 1723-1742.

[25] Rosen, B.N., Sandler, D.M. and Shani, D. (1991), "Social issues and socially responsible investment behavior: a preliminary empirical investigation", Journal of Consumer Affairs, Vol. 25 No. 2, pp. 221-234.

[26] Schueth, S. (2003), "Socially responsible investing in the United States", Journal of Business Ethics, Vol. 43 No. 3, pp. 189-194.

[27] Tippet, J. and Leung, P. (2001), "Defining ethical investment and its demography in Australia", Australian Accounting Review, Vol. 
11 No. 25 , pp. 44-55.

[28] Viviers S, Krüger J, Venter DJ. The relative importance of ethics, environmental, social and governance criteria. African Journal of Business Ethics 2012;6:120-32.

[29] Williams, G. (2007), "Some determinants of the socially responsible investment decision: a cross-country study", Journal of Behavioral Finance, Vol. 8 No. 1, pp. 43-57.

[30] Wins \& Bernhard Zwergel. 2016. Comparing those who do, might and will not invest in sustainable funds: a survey among German retail fund investors. Business Research 9:1, 51-99. 